\title{
The effects of reimbursement mechanisms on medical technology diffusion in the hospital sector in the Italian NHS
}

\author{
Massimo Finocchiaro Castro ${ }^{\mathrm{a}}$, Calogero Guccio ${ }^{\mathrm{b}, *}$, \\ Giacomo Pignataro $^{\mathrm{b}}$, Ilde Rizzo ${ }^{\mathrm{b}}$ \\ a Mediterranean University of Reggio Calabria, Department of Law and Economics, Via Tommaso Campanella, 38/A, 89125 Reggio \\ Calabria, Italy \\ b University of Catania, Department of Economics and Business, Corso Italia, 55, 95121 Catania, Italy
}

\section{A R T I C L E I N F O}

\section{Article history:}

Received 8 October 2012

Received in revised form

22 November 2013

Accepted 9 December 2013

\section{Keywords:}

Hospital care

Medical equipment

Prospective payment systems

DRG

Technology diffusion

Decentralization

\begin{abstract}
A B S T R A C T
Objectives: The aim of this study was to investigate how the differences across the regional reimbursement mechanisms and in particular the use of the DRGs impact on the level in the high technology equipment diffusion.

Methods: Based on hospital sector data at a regional level we build up indicators to measure the regional diffusion of high technological medical equipment in the period 1997-2007. These indicators are regressed on regional healthcare characteristics to investigate the relationship between the different reimbursement systems offered by Italian regions and the level of high technological medical equipment.

Results: Our results suggest that the per-case payment system is generally associated with a lower level of regional technology endowment per million of inhabitants, especially for the complex and expensive medical equipments.

Conclusions: Our findings cast some doubts that an effective regulation of reimbursement mechanisms cannot limit the excessive diffusion of medical equipment that is a relevant driver of the increase in expenditure.
\end{abstract}

(c) 2013 Elsevier Ireland Ltd. All rights reserved.

\section{Introduction}

Current reimbursement schemes imply different incentives for health care organisations, among which there are the ones related to the medical technology, which represents one of the major drivers of costs and an increasingly important input in the production of health. Several empirical studies have investigated the links between the pattern of medical technology, particularly medical equipment, and a few relevant factors, among which reimbursement mechanisms [1-3]. Most of these studies, however, are focused on specific technologies and, therefore, they are inherently limited to investigate specific features of the

\footnotetext{
* Corresponding author. Tel.: +39 095 7537744; fax: +39 0957537710. E-mail addresses: cguccio@lex.unict.it, guccio@unict.it (C. Guccio).
}

reimbursement mechanisms for the services requiring the employment of those technologies [4]. In this paper, we aim at enlarging the scope of previous investigations by considering the impact of the main features of general reimbursement mechanisms (e.g. cost per case vs. fee for service) on the high technology equipment diffusion at regional level.

For this purpose, we investigate how the differences across the regional reimbursement mechanisms in Italian NHS affect the level of the medical high technology equipment. These differences mainly regard the extent of the use of the Diagnosis Related Group (DRG) system to finance hospital care. Hence, we contribute to the existing empirical literature by providing an econometric analysis of the relationship between the different reimbursement systems offered by Italian regions and the level of high technology medical equipment at an aggregate regional level in 
the period 1997-2007, since data at hospital level are not available. Previous approaches proposed in the literature $[7,26]$ would not be really useful with respect to the aggregate regional data we are using, which refer to a wide bundle of technologies and providers in the area. In fact, the endowment of high technology medical equipment at aggregate regional level is affected by factors different from those influencing the technology adoption of a single hospital such as geographical dimension and population of the region, its socio-economic and health conditions, public-private mix and regulation of health care providers. Thus, to measure the technology endowment at regional level, we use aggregate indices of technology computed per millions of inhabitants and based on a weighted sum of the number of different pieces of equipment, where a vector of estimated normalised prices represents the weights.

Our results suggest, given the available dataset, that the per-case payment system is generally associated with a lower level of regional technology endowment per million of inhabitants, when controlling for variables related to demand and supply of hospital services. This effect is particularly relevant in the case of the most expensive medical equipment technology.

The paper is organised as follows: Section 2 reviews the main findings of the literature and briefly presents the Italian institutional framework, Section 3 describes our data set and develops the empirical analysis and Section 4 discusses our empirical results. Finally, Section 5 offers some concluding remarks and policy implications.

\section{Background}

\subsection{Medical technology diffusion and measurement issues}

Several studies show that medical technology ${ }^{1}$ is one of the most relevant drivers of the increase of public expenditures on health [5]. A broad definition of medical technology is frequent in studies on non-price competition that refer to both old processes and newly developed devices. Differently, the stream of research known as "medical arms race" focuses only on newly developed, expensive devices and processes [7], whereas other works investigate the factors affecting the rate of diffusion of new medical technologies [8].

The empirical literature connects health care expenditure and medical technology to explain the process of adoption of medical technology, considering several factors such as the degree of substitutability/complementarity between old and new technologies, the level of effort reduction and output improvement of medical innovation, the role of the costs of technological adoption in accordance with treatment expansion and substitution, the characteristics of the health care system, its financing and regulation

\footnotetext{
1 The OECD [6] lists the characteristics of medical technological change capable to have economic consequences: whether the new technology substitutes for old or is add-on to existing one; whether the new technology causes average cost reduction, quality improvement or reduction of risk to patients.
}

[4]. Among these factors, we focus on the effects of different reimbursement systems on the decisions of health care providers to adopt new technologies. In particular, under retrospective cost reimbursement system hospitals run no financial risk of investment in technology and, thus, this payment system leads to the "medical arms race", i.e. escalation of health care costs due to proliferation of expensive medical technology and devices [7]. ${ }^{2}$

In a prospective payment system, such as the DRG one, hospitals are encouraged to keep their average costs below the payment rate in order to avoid making a loss and, thus, affecting technology adoption $[25,46]$.

The effects of these incentives on the hospitals' adoption of technological innovations strictly depend on the country-specific institutional characteristics and on the kind of perspective payment system in use [24]. For instance, fixed global-budget schemes do not seem to foster technology adoption [20], whereas DRG based systems may favour the purchase of innovative technologies if they can reduce admission costs [7]. Moreover, it has to be considered that, in practice, the "pure" perspective model is hardly implemented since each country makes adjustments (see, for some European countries [47]).

From a theoretical perspective, the link between technology adoption and health insurance market $[9,10]$ and the connection between technology diffusion and reimbursement systems in an "ex-post" moral hazard framework [11] have been studied. Also, attention has been paid to the impact of different payment systems on the adoption of endogenously provided new technologies [12] and to the optimal investment decision mechanism in new health care technologies of hospitals [13].

Empirical studies on US [14,15] and Japanese hospitals [16] have shown that low prospective payment rates negatively affect the adoption of technologies, particularly cost-increasing ones, though the extent of this varies from case to case. In addition, a positive association between the degree of competition in the health care market and the propensity to adopt new technologies has been reported [17]. Looking across countries, the differences in technology diffusion can be explained by the different regulatory policies and payment systems to providers [18,19]. The financing of capital costs differs among countries. For instance [47], classify 11 European countries according to whether capital costs are financed via DRG or via specific budget lines and show no clear prevalence of one scheme (e.g. in Italy a mixed scheme is adopted [48]). ${ }^{3}$

From a more general perspective, decision-makers often choose technologies that are not necessarily the most effective or cost-effective ones, due to budgetary constraints and to the lack of detailed information on the effectiveness and costs of new medical services [6]. This is, indeed, the case for a strong contrast between doctors, asking for the most effective technologies regardless of their costs,

\footnotetext{
2 For a general discussion on the incentives in regulation mechanisms, see [45].

3 Six countries fund capital costs exclusively through the DRG system (Austria, UK, Estonia, Finland, Netherlands, Switzerland and Sweden). Five use only separate payments (Catalonia/Spain, Germany, Ireland, Portugal). Finally, two use both (France and Poland).
} 
and health care managers, who operate under strict budget constraints. Hence, most of the empirical works focusing on the factors affecting technology adoption analyse one or more technologies separately [3,8,21-25].

One of the most relevant problems when dealing with medical technology concerns the measurement of technology adoption and diffusion. Thus, it is necessary to consider that the "... analysis of individual technologies is limited by the idiosyncrasies of each technology's history, financing, and diffusion. Indices can ameliorate this problem but introduce their own problems. Indices can confound the data, as in the case of the Saidin index in which a hospital that adds five common services may have the same increase in the index as a hospital that adds one rare service..." [7, p. 445].

The most used approach to evaluate the diffusion of single medical technologies, at country or regional level, employs an index, computed as the number of devices or equipment per thousand or million inhabitants that considers each technology one at a time. To provide aggregate information about technology diffusion, it is, thus, necessary to employ an index that accounts for the whole technology stock. For instance [26], adopts an index of availability of hospital technology, (i.e. Saidin index [7]), that weights hospital technologies according to how rare they are among the sample of hospitals under consideration, keeping constant the set of technologies. Thus, the less diffused the set of technologies, the higher the value of the weight will be. ${ }^{4}$ However, the application of this index would not be really useful when using, as in our case, aggregate regional data, which refer to a wide bundle of technologies. In fact, the endowment of high technology medical equipment at aggregate regional level is affected by factors different from those influencing the technology adoption of a single hospital such as geographical dimension and population of the region, its socio-economic and health conditions, public-private mix and regulation of health care providers.

Being available only hospital aggregate data at regional level, we build an aggregate index of technology endowment (Equipment Endowment Index - EEI) considering both public and private accredited providers.

In details, we consider a weighted sum of the number of pieces of the different types of medical equipment and use as weights a vector of estimated normalised prices, keeping constant the set of medical equipment for each region. More formally, given a fixed set of medical equipment $k$, where $k=1, \ldots, K$, we assign each piece of medical equipment a weight $w_{k}$, with $w_{k}=E\left(p_{k}\right) / E\left(p_{\max }\right)$, where $E\left(p_{k}\right)$ is the estimated price of medical equipment $k$ and $E\left(p_{\max }\right)$ is the estimated price of the most expensive medical equipment in the set $K$. By instance, for the region $i$ in year $t$, the index, thus, is $\mathrm{EEI}_{i, t}=\Sigma_{k=1}^{K} w_{k} Q_{k, i, t} / \mathrm{POP}_{i, t}$, where $Q_{k, i, t}$ is the number of units of medical equipment $k$ inventoried in region $i$ in year $t$ and $\mathrm{POP}_{i, t}$ is the population of region $i$ in year $t$ in millions of inhabitants. The index is computed per

\footnotetext{
${ }^{4}$ However, to use Saidin index in a time series or panel data analysis, it is necessary to employ a fixed vector of weights with respect to a base year.
}

millions of inhabitants to make possible the comparison between regions with different populations.

Thus, for a given set of medical equipment and vector of estimated prices, the proposed index directly provides a measure of the hospital sector endowment of high technology medical equipment for each region and for each period of observation. Moreover, it makes the different endowments of high technology medical equipment of each regional hospital sector comparable. It has, however, to be noted that our choice in terms of the set of medical equipment has been constrained by data availability. In particular, we have included in our analysis only the pieces of medical equipment for which we have gathered all the required information for the whole observation period. ${ }^{5}$

Finally, we acknowledge that our index does not distinguish between innovative and traditional medical equipment. However, the computation of an index of new technology diffusion through the normalisation of a given set of medical equipment is out of the scope of the present paper.

\subsection{Mechanisms for financing hospital care in Italy}

Italy may represent an interesting case study to test the impact of different financing mechanisms on the process of technology adoption because the financing system for hospital care is significantly differentiated across regions. We will focus here on a few characteristics of this system, which we deem relevant for the specific purposes of our analysis.

In early 90s, Italy reformed the organisation of its health care system, changing, among other things, the financing mechanism for health care providers, until then mainly based on actual expenditure [27-29]. These reforms were also characterised by a wide devolution of the responsibility for the organisation and financing of health care to regional governments.

The first important feature of the funding system for hospital care is the adoption of two basic financing criteria: (i) lump sum transfers, related to the provision of specific health care services by hospitals and (ii) activity based payments. The former is used to finance the provision of services, for which "tariffs are deemed inadequate or inappropriate" [27], such as integrated care, prevention activities, emergency services, experimental programmes, and transplants. ${ }^{6}$ Regions have full autonomy in the identification of these services and, therefore, may alter the composition of hospital funding and reduce the role of activity based payments. Lump sum transfers should be determined on the basis of the efficient cost of their provision.

\footnotetext{
${ }^{5}$ For a detailed description of the adopted set of technologies, see Appendix A.

${ }^{6}$ The inappropriateness of tariffs for financing this type of services is due to different reasons: some services, like transplants have a regional interest, since they are very few and require sophisticated technologies, so that they need to be concentrated in one or a few hospitals; other services, like the ones related to emergency, require an amount of resources independent of demand; there are peculiarities of some hospitals (like teaching hospitals) difficult to be dealt with in the tariff mechanism $[30,34]$
} 
The rest of inpatient care is financed through a per case funding system, based on tariffs ${ }^{7}$ related to the DRG classification of discharges, version $24,{ }^{8}$ and on a differentiation of ordinary, day hospital and day surgery cases. The tariffbased system exhibits different features across regions, too. As it has been pointed out by [38] in Northern and Central regions DRGs are consistently used to provide incentives to producers while in Southern regions such a role is weakened by the coexistence with other funding criteria such as past and current expenditure and deficits.

Secondly, the financing mechanism varies also according to the institutional nature of hospitals. In the Italian NHS, public provision of hospital care takes place through different types of providers, public as well as accredited private ones. Moreover, there are two main types of public hospitals: the ones run by local health authorities and the independent hospitals, which enjoy full managerial autonomy. The above criteria do not apply to public hospitals directly managed by local health authorities, while they are in use for funding public independent and accredited private hospitals. Local health authorities are generally funded by the regional governments according to weighted capitation, ${ }^{9}$ and the activity of their hospitals is financed through this budget. Therefore, they are “... de facto financed on the basis of the consumption of production factors (personnel, goods and services, etc.)" (Source [32] our translation).

Moreover, tariffs can play different roles depending on the type of hospital care provider. They represent the "real price" for the accredited private hospitals while for public ones they can be used just as a regional device to assess hospital activity and to determine the global hospital budget [32]. Moreover, Regions can discriminate tariffs across providers to make them closer to their actual costs and local specificities [33].

A third difference refers to the implementation of expenditure control measures, deemed to control the tendency of providers to increase the volume of services as a consequence of activity based payments: some Regions (e.g. Lombardy) have set caps, ceilings or targets at either regional, local health authorities or hospital level while others (e.g. Tuscany) control volumes of production by using bilateral contracts (between local health authorities and hospitals $).{ }^{10}$

Overall, in the funding system for hospital care the role of regional governments is worth mentioning. They take relevant decisions in this area, which shape the funding system and can have a significant impact on the adoption of medical technology. As already mentioned, regional governments choose which services are to be financed through lump sum transfers. ${ }^{11,12}$ The choices they make in this

\footnotetext{
7 Outpatient services are financed according to a fee-for-service mechanism.

8 This version was introduced, at a national level, in 2009 [31].

9 Weights, when used, are generally related to age.

10 For further details, see [28].

11 It must be noted that most regions provide these funds only to public independent hospitals, even if in a few ones accredited private hospitals benefit from this financial source too.

12 There are other important funding regional decisions that are not discussed in this paper: each region may determine its own tariffs, it can
}

area affect the relative weight of lump sum versus activity based payments, in the overall financing of hospital care and, consequently, the nature of the financial incentives to the adoption of medical technology. Though data are scarce, some of the few estimates available (for some regions) show that the percentage of hospital care expenditure financed through lump sum transfers ranges from $1 \%$ in Umbria to $20 \%$ in Lombardy [32].

Regional governments also choose organisational overall arrangements of hospitals, whether they are run by local health authorities or they enjoy full managerial autonomy, as well as the degree of involvement of private hospitals in the provision of services, through their accreditation policy. Again here, there is a relevant variability of organisational choices across regions: for instance, Lombardy has no hospital run by local health authorities, while local health authorities of Veneto run most of the hospitals of that region.

The data available at a regional level do not allow a quantitative representation of all the differences in the regional financing systems discussed above. We are able to consider only the extent of the difference between the funding system for public hospitals directly managed by local health authorities and the one for all other hospitals (public independent and accredited private hospitals). It will be measured, for each region, by the ratio of beds used by hospitals not run by local health authorities with respect to the total number of hospital beds in the region.

This indicator should provide a rough idea of the extent to which the tariff system is used, in each region, for financing hospital care. At the same time, we are aware that this indicator is not able to represent the actual extent of use of tariffs, since it does not capture the variability of lump sum funding across regions. Moreover, the same phenomenon can be expressed in financial terms, using the ratio between the tariff-based regional spending over the not tariff-based regional spending. This ratio is identified as a measure of the actual use of DRGs by [38] while the ratio in terms of beds can be considered as a measure of potential use of DRGs.

Table 1 shows, in columns 4 and 5 , the values of the above indicators computed by [38] with reference to 2005. Also, in columns 2 we report the year of DRG adoption and in column 3, we distinguish those regions that have established their own DRG tariffs from those ones that have opted for the national DRG rates. The measures of potential and actual use of DRGs at the regional level for the year 2005 reported in Table 2 show a large interregional variations as well as a high correlation between the two measures. However, it needs to be stressed that the two measures can diverge due to both lower average bed occupancy rates and/or the regional choice to increase the share of non DRGbased funding allocated to different providers and by the existence of expenditure caps, ceilings and targets.

Though tariffs are meant to cover overall costs, including therefore the expenditure for technical equipment, still this type of input can also be financed through specific

differentiate them by type of providers, and it can implement expenditure caps, ceilings and targets. 
Table 1

Regional variation in DRG use.

\begin{tabular}{|c|c|c|c|c|}
\hline Region & $\begin{array}{l}\text { Year of DRG system } \\
\text { introduction }^{\mathrm{a}}\end{array}$ & $\begin{array}{l}\text { Reference fee schedule (at } \\
\text { year 2005) }\end{array}$ & $\begin{array}{l}\text { Potential use of DRG (at } \\
\text { year 2005) }\end{array}$ & $\begin{array}{l}\text { Actual use of DRG (at year } \\
2005)^{b}\end{array}$ \\
\hline Abruzzo & 1996 & National & 16.1 & 17.0 \\
\hline Basilicata & 1997 & National & 48.7 & 13.3 \\
\hline Bolzano A.P. & 1995 & National & 15.0 & 5.7 \\
\hline Calabria & 1995 & National & 64.4 & 7.8 \\
\hline Campania & 1996 & National & 67.2 & 13.6 \\
\hline Emilia Romagna & 1996 & Regional & 49.3 & 21.7 \\
\hline Friuli V. G. & 1995 & National & 71.0 & 21.7 \\
\hline Lazio & 1995 & National & 74.3 & 27.0 \\
\hline Liguria & 1995 & National & 53.9 & 26.7 \\
\hline Lombardy & 1995 & Regional & 99.2 & 34.4 \\
\hline Marche & 1995 & National & 42.0 & 17.7 \\
\hline Molise & 1995 & National & 28.3 & 12.6 \\
\hline Piedimont & 1995 & Regional & 57.6 & 26.9 \\
\hline Puglia & 1995 & National & 45.2 & 24.2 \\
\hline Sardegna & 1995 & National & 30.5 & 4.7 \\
\hline Sicily & 1995 & Regional & 73.8 & 9.5 \\
\hline Toscana & 1995 & Regional & 43.6 & 17.3 \\
\hline Trento A.P. & 1997 & National & 29.4 & 5.7 \\
\hline Umbria & 1995 & Regional & 52.1 & 21.9 \\
\hline Valle d'Aosta & 1995 & National & 0.0 & 3.3 \\
\hline Veneto & 1995 & Regional & 34.1 & 20.1 \\
\hline
\end{tabular}

a Age.NAS, Italian Minister of Health.

b [38].

capital expenditure funds. Reasons for excluding, at least partially, capital costs from the activity-based financing include retaining regional/central control over investment decisions (e.g. not only high expensive technical equipment but also new building, etc.) while giving hospitals the opportunity to better control their costs, at least in the short run [39]. Indeed, the extent of capital funding system for technical equipment is likely to vary across regions: capital expenditure has three different sources of financing: state/regional transfers, debt and providers' own funds and no data are available on the dimension of these different items. However, it is relevant to stress here that activity based payments still seem to play a relevant role in financing technology. In fact as stated by [27, p. 257] "Italian DRG

Table 2

Variables and data sources.

\begin{tabular}{|c|c|c|}
\hline Variable & Definition & Source \\
\hline \multicolumn{3}{|l|}{ Dependent variables } \\
\hline EEI & $\begin{array}{l}\text { Index of endowment of equipment (per million } \\
\text { population), at regional level }\end{array}$ & $\begin{array}{l}\text { Our elaboration on data by Italian Ministry of Health } \\
\text { and "Osservatorio Prezzi e Tecnologie" }\end{array}$ \\
\hline H_ EEI & $\begin{array}{l}\text { Index of endowment of the } 4 \text { most expensive pieces of } \\
\text { equipment (per million population), at regional level }\end{array}$ & $\begin{array}{l}\text { Our elaboration on data by Italian Ministry of Health } \\
\text { and "Osservatorio Prezzi e Tecnologie" }\end{array}$ \\
\hline \multicolumn{3}{|l|}{ Covariates } \\
\hline GDP_POP & $\begin{array}{l}\text { Regional per capita gross domestic product at } 2000 \\
\text { fixed prices }\end{array}$ & $\begin{array}{l}\text { Our elaboration on data by ISTAT, Health for all } \\
\text { database }\end{array}$ \\
\hline OLD & $\begin{array}{l}\text { Percentage of population aged } 65 \text { and over, at regional } \\
\text { level }\end{array}$ & $\begin{array}{l}\text { Our elaboration on data by ISTAT, Health for all } \\
\text { database }\end{array}$ \\
\hline DISCHARGE_POP & $\begin{array}{l}\text { Acute hospital discharge rate per } 1000 \text { inhabitants, at } \\
\text { regional level }\end{array}$ & ISTAT, Health for all database \\
\hline AMBULATORY_POP & $\begin{array}{l}\text { Ambulatory diagnosis and laboratory tests per } 1000 \\
\text { inhabitants, at regional level }\end{array}$ & ISTAT, Health for all database \\
\hline INFLOW & $\begin{array}{l}\text { The share of hospital admissions in region } i \text { that are } \\
\text { provided to non-residents }\end{array}$ & ISTAT \\
\hline BEDS_POP & Number of acute hospital beds, at regional level & Our elaboration on data by Italian Ministry of Health \\
\hline PHYS_POP & $\begin{array}{l}\text { Number of physicians working in hospitals per } 1000 \\
\text { inhabitants, at regional level }\end{array}$ & Our elaboration on data by Italian Ministry of Health \\
\hline MIX_P\&P & Share of regional hospital beds owned by private sector & Our elaboration on data by Italian Ministry of Health \\
\hline CASE_MIX & $\begin{array}{l}\text { Case-mix index of inpatient hospital production } \\
\text { computed on DRG weights, at regional level }\end{array}$ & Our elaboration on data by Italian Ministry of Health \\
\hline DRG & $\begin{array}{l}\text { Proportion of total beds owned by public independent } \\
\text { and private accredited hospitals, at regional level }\end{array}$ & Our elaboration on data by Italian Ministry of Health \\
\hline REG_DRG & $\begin{array}{l}\text { Dummy variable for regional DRG ( }=1 \text { if region have } \\
\text { established their own DRG tariffs, } 0 \text { if region have } \\
\text { opted for the national DRG rates) }\end{array}$ & $\begin{array}{l}\text { Our elaboration on data provided by Regional } \\
\text { administrations }\end{array}$ \\
\hline TREND & Linear time trend & Our elaboration \\
\hline
\end{tabular}


tariffs are setting to cover the most of hospital costs, including administration costs and overheads, but excluding capital costs.......In theory, tariffs are not expected to cover capital costs of public providers because there are specific budget lines for capital spending. In practice, however, those budget lines make available very limited funds and providers are forced to fund capital investments from operating revenues..."

Moreover, differences among different providers also exist; in fact, only public hospitals are eligible for specific capital financing while private accredited ones are not [27]. Therefore, it is reasonable to assume that tariffs contribute to cover capital costs in the Italian system.

Finally, to capture residual regional differences in financing mechanisms that could affect technology diffusion [35], we can distinguish those regions that have established their own DRG tariffs from those ones that have opted for the national DRG rates (see Table 1).

\section{Materials and methods}

We use data for the Italian regions in the 1997-2007 period. Thus, the estimated models use a combination of time-series and cross-sectional data for a total of 219 observations. ${ }^{13}$ The data on technology medical equipment are available only at regional level and refer to 16 different pieces of medical technical equipment. ${ }^{14}$ Our work, thus, departs from the stream of literature, which takes into consideration wider definitions of medical technology [25] or specific equipment [20]. For computation purpose, we will use the aggregate index of technology endowment computed for the hospital sector of each region (EEI) as described in Section 2.1. Since the literature [22,25] shows that the relative high price of technology plays a relevant role in its adoption, we have also focused on the four most expensive pieces of equipment in our dataset (linear accelerators and components, computerised gamma camera, CT - scanner and MRI), and we have computed the regional indices for this subset of equipment (H_EEI). Fig. 1 reports the plot of the indices by each region.

As expected, the H_EEI index is always lower than EEI for each region. Also, even if there are differences in the values of the two indexes among regions, both seem to be characterised by a common increasing trend, although at a different rate.

The available data allow us to disentangle the two indices into two components, one referring to public hospitals and another referring to private accredited hospitals at regional level. Fig. 2 shows the decomposition of the EEI index for these two groups of providers. ${ }^{15}$ Also in this case, several differences among regions can be noted. Moreover, the levels of medical equipment of public hospitals are always higher than those of the private accredited hospitals and the trends of the two components differ both among regions and within the same region.

\footnotetext{
13 Our panel is unbalanced because the first available year for the region Valle d'Aosta is 1998.

14 See Appendix A.

15 Detailed statistics on the indices are reported in Tables A2 and A3 of the Appendix A.
}

\subsection{Materials}

Our data come from different sources. The inventory of medical equipment at regional level has been provided by the Italian Ministry of Health. To compute the weights for our indices, we employ data provided by the Italian Ministry of Health and the Observatory of prices and technologies (Osservatorio Prezzi e Tecnologie), regarding the prices of the different pieces of equipment. ${ }^{16}$

The other explanatory variables are collected from Italian statistical office (ISTAT) and Italian Ministry of Health. Table 2 describes the variables adopted and their sources, whereas Table 3 provides the descriptive statistics.

\subsection{Methods}

To estimate the impact of reimbursement mechanisms on the diffusion of medical technologies we assume that our dependent variable (EEI and H_EEI, respectively) is a linear function of some covariates that are grouped in demand, supply, and regional regulation factors [20]. ${ }^{17}$ For each index, the model takes the following form:

$\mathrm{EEI}_{\mathrm{it}}^{*}=\mathrm{f}\left(\right.$ demand $_{\mathrm{it}}$, supply $_{\mathrm{it}}$, regulation $\left._{\mathrm{it}}\right)$

$\mathrm{H}_{-} \mathrm{EEI}_{\mathrm{it}}^{*}=\mathrm{f}\left(\right.$ demand $_{\mathrm{it}}$, supply $_{\mathrm{it}}$, regulation $\left._{\mathrm{it}}\right)$

where $i$ denotes the region and $t$ the year.

Starting from the vector of demand-side covariates, we employ the real per capita income (GDP_POP), the proportion of population aged 65 and over (OLD), the acute hospital discharge rate per 1000 inhabitants (DISCHARGE_POP), the ambulatory diagnosis and laboratory tests per 1000 inhabitants (AMBULATORY_POP) and the inflow rate (INFLOW) that represents the share of hospital admissions in a given region provided to non-residents. The socio-economic variables are usually adopted in literature [20] and we expect that all of them positively affect the level of medical technology equipment of the regional hospital system. The use of medical technology equipment at regional level may be also affected by the effective demand of hospital services. ${ }^{18}$ For this reason, we expect that DISCHARGE_POP and AMBULATORY_POP positively affect our indices. However, it has to be noted that data on the demand of ambulatory services provided by hospitals are not available. Thus, our variable can be considered as a proxy for the demand of ambulatory services provided by hospitals. In addition, a regional hospital system experiencing high inflow rate of non-resident patients, ceteris paribus, should invest more on medical technical equipment to meet the additional demand.

As for the supply-side variables, we use total acute hospital beds per 1000 inhabitants (BEDS_POP) and the number of physicians working in hospitals per 1000 inhabitants (PHYS_POP). Both variables are inputs of the production of hospital services and should positively affect the

\footnotetext{
16 For further details on the employed dataset, see [36].

17 We also run a log-log specification of the models. The results, available upon request, are altogether comparable with those reported.

18 We thank both reviewers for raising our attention on this point.
} 


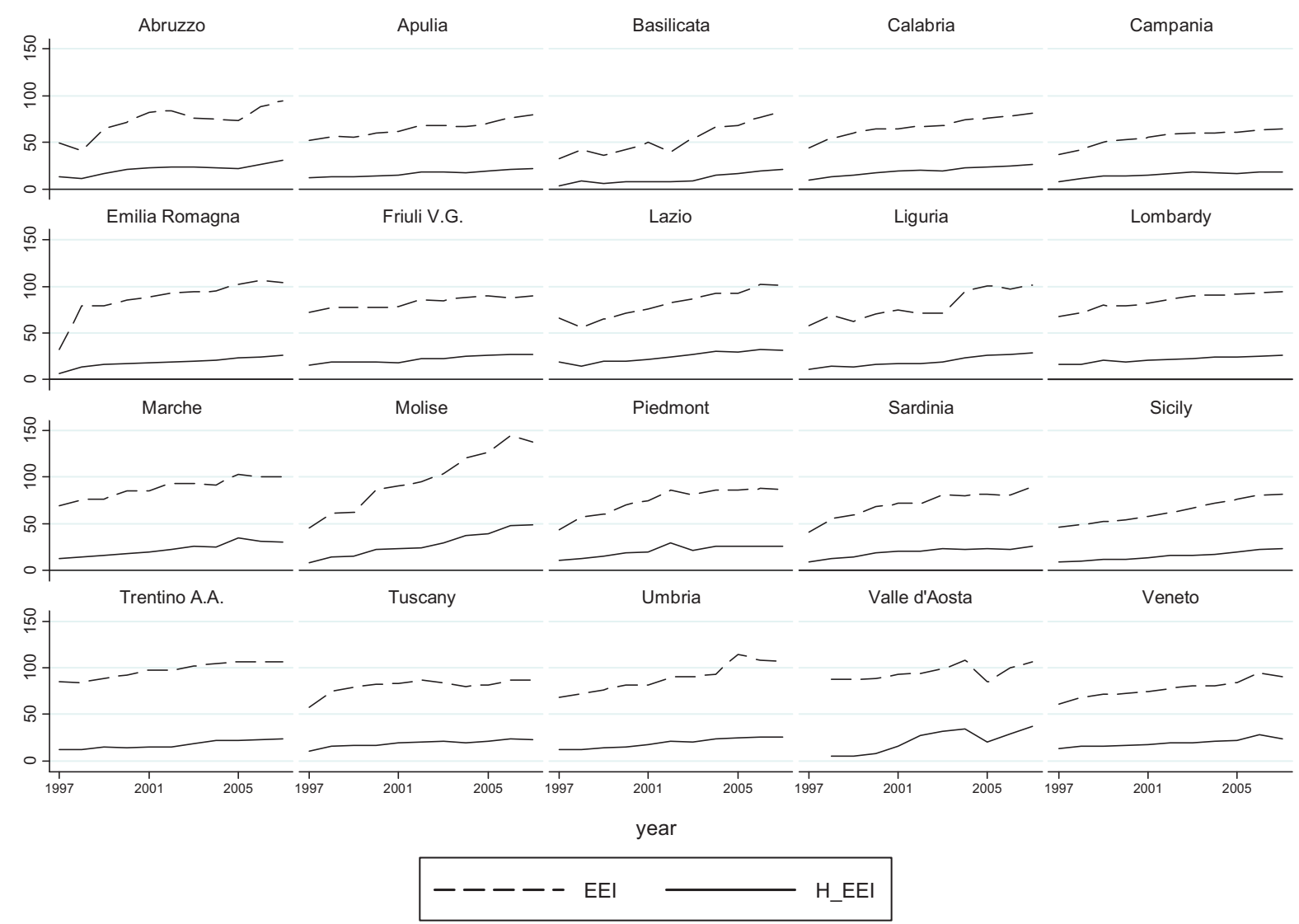

Fig. 1. Trends of EEI and H_EEI indexes for each Italian region (aggregate data at regional level). Source: our elaboration based on data provided by Italian Minister of Health and by Osservatorio Prezzi e Tecnologie.

Table 3

Descriptive statistics.

\begin{tabular}{|c|c|c|c|c|c|}
\hline Variable & Obs. & Mean & Std. Dev. & Min & $\operatorname{Max}$ \\
\hline EEI & 219 & 77.976 & 18.690 & 32.226 & 144.195 \\
\hline H_ EEI & 219 & 19.609 & 7.021 & 3.582 & 49.288 \\
\hline GDP_POP & 219 & $22,822.187$ & 6926.268 & $10,334.270$ & $38,814.450$ \\
\hline OLD & 219 & 19.522 & 2.907 & 13.020 & 26.740 \\
\hline DISCHARGE_POP & 219 & 155.854 & 25.442 & 103.890 & 222.780 \\
\hline AMBULATORY_POP & 219 & 116.453 & 16.063 & 86.300 & 156.400 \\
\hline INFLOW & 219 & 9.369 & 5.445 & 3.025 & 25.521 \\
\hline BEDS_POP & 219 & 4.463 & 1.649 & 2.917 & 14.233 \\
\hline PHYS_POP & 219 & 1.966 & 0.257 & 1.136 & 2.723 \\
\hline MIX_P\&P & 219 & 16.223 & 11.355 & 0.596 & 55.377 \\
\hline CASE_MIX & 219 & 0.994 & 0.087 & 0.830 & 1.150 \\
\hline DRG & 219 & 0.475 & 0.228 & 0.000 & 0.992 \\
\hline REG_DRG & 219 & 0.336 & 0.474 & 0.000 & 1.000 \\
\hline
\end{tabular}

Source: authors' elaboration on data provided by Italian Ministry of Health, by Osservatorio Prezzi e Tecnologie and by ISTAT.

dependent variable, since most of the medical equipment can be considered as a complement to these inputs. Moreover, as a proxy for the level of hospital competition in each region, we consider the public-private $\operatorname{mix}$ (MIX_P\&P), measured in terms of the share of regional hospital beds owned by the private accredited providers.

The effects of highly competitive environment in the hospital service on technology diffusion cannot be easily measured. Overall, the empirical literature generally finds that both fixed price competition and managed care appear to lead to slower diffusion rate [1]. Thus, we expect that a competitive environment constrains medical technology diffusion at regional level. ${ }^{19}$

\footnotetext{
19 Negative effects on technology diffusion might also depend on the generally low complexity and case-mix of hospital care in private accredited hospitals.
} 

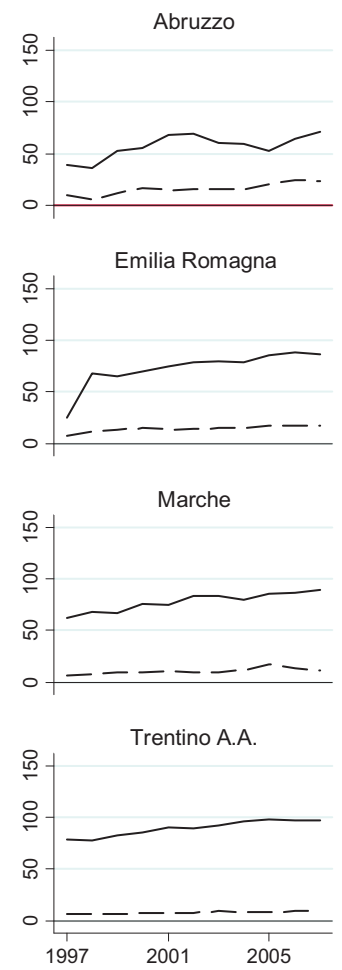

Apulia

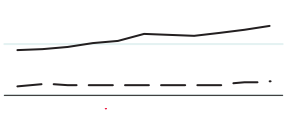

Friuli V.G.
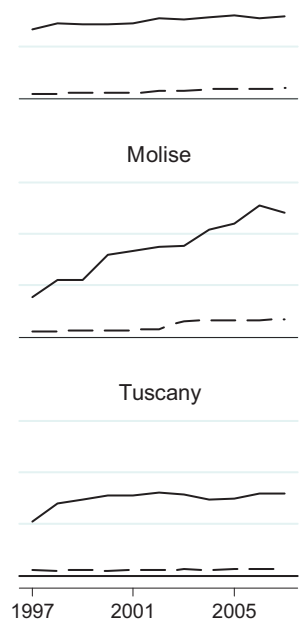

Basilicata
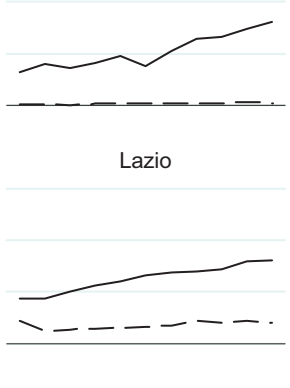

Piedmont

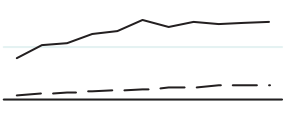

Umbria

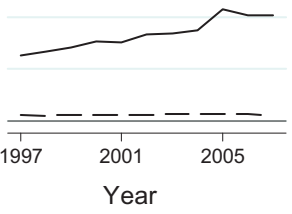

Calabria

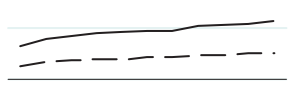

Liguria
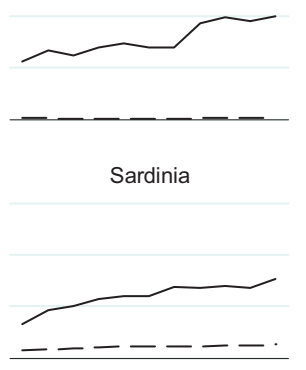

Valle d'Aosta

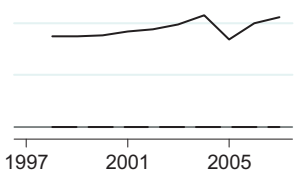

Campania
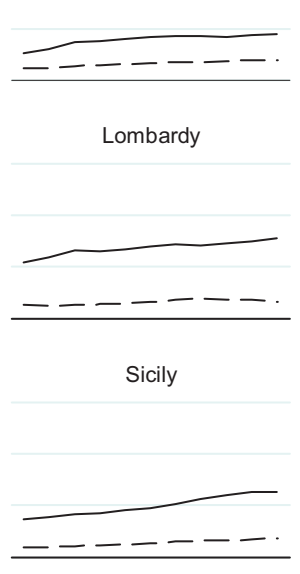

Veneto

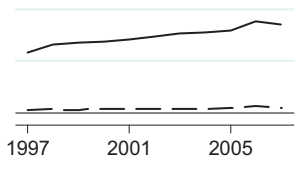

Fig. 2. Decomposition of EEI index into the component referring to public hospitals and the component referring to private hospitals (aggregate data at regional level).

Source: our elaboration based on data provided by Italian Minister of Health and by Osservatorio Prezzi e Tecnologie.

Finally to capture the effects on hospital production of technology availability we employ a case-mix index of regional hospital production build on DRG weights (CASEMIX), e.g. a higher inpatient regional case-mix leads to a larger endowment of medical equipment. Moreover, this variable allows us to control, at least partially, for overinvestment in high technology.

The other covariates, related to regional regulation, should catch the effects due to the differences across the regional funding systems for hospital care. For this purpose, we employ two variables. As a proxy for the extent to which the DRG per case payment system is used in each region, we consider the share of total hospital beds owned by public independent "Aziende Ospedaliere" and private accredited hospitals (DRG). Even if the variable DRG is a very rough representation of the differences in financing systems across Italian regions, ${ }^{20}$ it certainly captures the relative size, in each region, of two large group of hospitals, which are strongly characterised, among others, by differences in management and, above all, in financing. ${ }^{21}$ Thus,

\footnotetext{
20 The same framework has been employed to quantify the extent to which the DRG payment system is adopted in each Italian region also by [52].

${ }^{21}$ Italian regions adopt the tariff system to finance only the public independent and the private accredited hospitals [51]. Hospitals managed by
}

we expect that the use of tariffs, enhancing budget constraints, exerts a negative effect on technology diffusion at regional level.

We are well aware that the regional differences in the implementation of the tariff system, within the subset of hospitals including the public independent and private accredited ones, are not fully captured by our variable (DRG). Therefore, to capture residual regional differences in the financing mechanism we distinguish, through a dummy variable, between the regions that have established their own DRG tariffs and the regions that have opted for the national DRG rates (REG_DRG ${ }^{22}$ ). The expected sign of this variable is ambiguous since the overall effect on technological diffusion will depend on the specific implementation of DRG system in each region.

\footnotetext{
local health authorities are completely outside the tariff mechanism: they are financed through the budget of the local health authority, on the basis of their input costs [33]. The revenues to local health authorities for the hospital activity they manage directly through their hospitals are part of the general revenues they receive from the region, which depend on a per capita basis.

${ }^{22}$ Along the observation period, there have been few changes in the fee schedule chosen by Italian regions as reported in detail by $[28,49,50]$. These changes have been taken into account in the way we have computed our variable.
} 
Table 4

Diagnostic for the base models.

\begin{tabular}{lll}
\hline Test & Results \\
\cline { 2 - 3 } & $(1 \mathrm{a})$ & $(1 \mathrm{~b})$ \\
\hline Autocorrelation $^{\mathrm{a}}$ & $F(1,20)=1.831 ;$ & $F(1,20)=2.293 ;$ \\
& $p$-value 0.1169 & $p$-value 0.0783 \\
Breusch-Pagan LM $^{\mathrm{b}}$ & $131.571 ; p$-value & $163.501 ; p$-value \\
& 0.0000 & 0.0000 \\
Hausman $^{\mathrm{c}}$ & $6.074 ; p$-value & $7.943 ; p$-value \\
& 0.0000 & 0.0000 \\
\hline
\end{tabular}

a Reports test for autocorrelation in linear panel-data proposed by [37: pp. 282-283].

b Reports Breusch-Pagan test ( $H_{0}$ that pooled OLS model is adequate, in favour of the fixed effect alternative).

c Reports Hausman test $\left(H_{0}\right.$ that the random effects model is consistent, in favour of the fixed effects model).

Finally, we control for trends in technology availability over time using a linear time trend (TREND) and, we check for the impact of technological change adding a set of year dummy variables [20].

To choose the most appropriate estimator for Eqs. (1a) and (1b), we first test for group-wise heteroskedasticity and autocorrelation. Table 4 reports the results of the performed diagnostic test. The test for autocorrelation in panel-data models ([37]: pp. 282-283) does not accept the hypothesis of no first-order autocorrelation in the data. Moreover, the results of the diagnostic for panel data (Breusch-Pagan's test and Hausman's test) suggest that fixed effect model is not adequate for the nature of the data. Based on these results feasible GLS with group-wise heteroskedasticity and first-order autocorrelation, is the estimation technique adopted in all models. ${ }^{23}$

\section{Results}

\subsection{Baseline results}

The empirical analysis consists of the estimation of several variants of (1a) and (1b), using different independent variables and different subsamples taken from our dataset. The estimates reported in Table 5 refer to the regional diffusion of medical equipment, using the overall regional endowment index (EEI) that has been computed on the 16 different pieces of equipment. Differently, Table 6 reports the estimates for the high technology diffusion index (H_EEI) referring to the four most expensive types of equipment.

In each table, Model 1 considers only the regulation control variable DRG, whereas Model 2 adds REG_DRG to control for residual regional differences in the financing mechanisms. Models 3 and 4 depart from specifications of Model 1 and 2, adding a set of year dummy variables to check for the impact of technological change. Furthermore, Models 5 and 6 restrict the sample to the 15 Italian regions,

\footnotetext{
23 As suggested by [37: pp. 257-264] when dealing with simple forms of autocorrelation or group-wise heteroskedasticity is prudent to employ feasible GLS estimator.
}

identified as "ordinary statute" regions, so as to account for a relevant institutional difference across the regions. ${ }^{24}$

The results are robust, with a good explicative power and generally in line with the main conclusions reached in the literature. As expected, all demand and supply related variables are generally significant and they positively affect the endowment of equipment of regions, implying that technological diffusion can be justified both as a response to the demand of hospital services and as an input in the production process. Moreover, our results outline that competition, measured by (MIX_P\&P), may have a negative impact on the regional endowment of equipment. However, since private accredited hospitals generally have a low level of complexity and case-mix, this variable may capture the effects of the high weight of private sector on our indexes of technology diffusion. ${ }^{25}$

Also, the variable CASE-MIX turns out to be generally significant and with a positive sign. Thus, as expected, the regions with high complexity of care show a high level of endowment of medical equipment.

Finally, the results show that those regions that have a smaller hospital supply financed through the activity based payment system, ceteris paribus, have a bigger equipment endowment (the DRG variable is significant and negative). This finding suggests that the per case payment system provides effective incentives to constrain technology adoption. Indeed, budget constraints may be more stringent for hospitals paid in such a way, in terms of both the financial resources they get and of the incentive to monitor the costs they provide for managers and doctors. Moreover, the dummy variable referring to the residual regional differences in the adoption of financing mechanisms (REG_DRG) turns out to be positive but generally not significant.

The above results are robust for both indices, regardless of the size of the sample under analysis. The extent to which per case payment system is used to finance the regional supply of hospital care by each region is more effective in constraining the medical equipment diffusion in the case of the most expensive technologies (H_EEI). To show this result, Table 7 reports the elasticities of the variable DRG for each index.

\subsection{Robustness checks and extensions}

In this section, we report the results of further tests run to account for the reliability and robustness of our findings. ${ }^{26}$

First, one would argue that a financial variable better measures the 'true' allocation of resources on a DRG basis and, therefore, the deriving incentive scheme.

\footnotetext{
24 In Italy there are 15 ordinary statute regions (Regioni a Statuto Ordinario) and five special statute regions (Regioni a Statuto Speciale). The five regions (Valle d'Aosta, Trentino Alto Adige, Friuli Venezia Giulia, Sicily and Sardinia) with special statutes have broader competencies and spending powers than the ordinary ones and enjoy correspondingly larger tax autonomy.

${ }^{25}$ To support this rationalisation we also observe that in Table 6 the variable, although negative, becomes not significant.

26 Due to tight constraints on the length of the paper, all the estimates discussed in this section are not reported here but are available from the authors upon request.
} 
Table 5

Econometric results for overall regional endowment index (EEI).

\begin{tabular}{|c|c|c|c|c|c|c|}
\hline Model & (1) & $(2)$ & (3) & (4) & (5) & (6) \\
\hline Dependent variables & EEI & EEI & EEI & EEI & EEI & EEI \\
\hline \multirow[t]{2}{*}{ Constant } & $-18.671^{* * *}$ & $-18.317^{* * *}$ & $-20.234^{* * *}$ & $-20.843^{* * * *}$ & $-25.367^{* * *}$ & $-26.580^{* * *}$ \\
\hline & $(7.407)$ & $(7.311)$ & $(7.798)$ & $(7.741)$ & $(9.605)$ & $(10.847)$ \\
\hline \multirow[t]{2}{*}{ GDP_POP } & $0.001^{* * *}$ & $0.001^{* * *}$ & $0.001^{* * *}$ & $0.001^{* * *}$ & $0.001^{* * *}$ & $0.001^{* * *}$ \\
\hline & $(0.000)$ & $(0.000)$ & $(0.000)$ & $(0.000)$ & $(0.000)$ & $(0.000)$ \\
\hline \multirow[t]{2}{*}{ OLD } & $0.180^{* * *}$ & $0.173^{* * *}$ & 0.141 & 0.187 & 0.214 & 0.210 \\
\hline & $(0.072)$ & $(0.068)$ & $(0.122)$ & $(0.108)$ & $(0.151)$ & $(0.151)$ \\
\hline \multirow[t]{2}{*}{ DISCHARGE_POP } & $0.146^{* * * *}$ & $0.147^{* * *}$ & $0.162^{* * *}$ & $0.159^{* * *}$ & $0.197^{* * *}$ & $0.209^{* * * *}$ \\
\hline & $(0.039)$ & $(0.039)$ & $(0.031)$ & $(0.031)$ & $(0.033)$ & $(0.035)$ \\
\hline \multirow[t]{2}{*}{ AMBULATORY_POP } & $0.344^{* *}$ & $0.310^{*}$ & 0.080 & 0.071 & $0.274^{* * * *}$ & $0.268^{* * *}$ \\
\hline & $(0.154)$ & $(0.160)$ & $(0.109)$ & $(0.101)$ & $(0.095)$ & $(0.099)$ \\
\hline \multirow[t]{2}{*}{ INFLOW } & $0.414^{* *}$ & $0.447^{* *}$ & $0.387^{* * *}$ & $0.417^{* * *}$ & 0.291 & 0.311 \\
\hline & (0.169) & $(0.177)$ & $(0.158)$ & $(0.164)$ & $(0.221)$ & $(0.207)$ \\
\hline \multirow[t]{2}{*}{ BEDS_POP } & 0.109 & 0.174 & -0.117 & 0.047 & -0.182 & 0.022 \\
\hline & $(0.772)$ & $(0.751)$ & $(0.881)$ & $(0.918)$ & $(0.801)$ & $(0.784)$ \\
\hline \multirow[t]{2}{*}{ PHYS_POP } & $17.127^{* * *}$ & $17.026^{* * * *}$ & $14.244^{* * *}$ & $14.506^{* * *}$ & $11.776^{* * *}$ & $13.175^{* * *}$ \\
\hline & (3.828) & (3.772) & (3.031) & (3.025) & $(2.682)$ & $(2.443)$ \\
\hline \multirow[t]{2}{*}{ MIX_P\&P } & $-0.184^{* *}$ & $-0.181^{* *}$ & $-0.153^{*}$ & -0.141 & -0.121 & -0.123 \\
\hline & $(0.094)$ & $(0.094)$ & $(0.089)$ & $(0.090)$ & $(0.103)$ & $(0.104)$ \\
\hline \multirow[t]{2}{*}{ CASE_MIX } & $2.041^{* * *}$ & $1.981^{*}$ & 1.718 & 1.734 & $2.337^{* * *}$ & $2.275^{* * *}$ \\
\hline & $(0.976)$ & $(1.014)$ & $(1.270)$ & $(1.314)$ & $(0.864)$ & $(0.853)$ \\
\hline \multirow[t]{2}{*}{ DRG } & $-13.567^{* * *}$ & $-13.273^{* * *}$ & $-15.041^{* * *}$ & $-15.954^{* * *}$ & $-9.319^{* *}$ & $-9.665^{* *}$ \\
\hline & $(3.057)$ & (3.092) & $(3.064)$ & $(2.975)$ & $(4.692)$ & $(4.493)$ \\
\hline \multirow[t]{2}{*}{ REG_DRG } & - & 0.839 & - & 1.345 & - & $5.866^{* * *}$ \\
\hline & & $(1.202)$ & & $(1.050)$ & & $(1.426)$ \\
\hline \multirow[t]{2}{*}{ TREND } & $2.433^{* * *}$ & $2.451^{* * *}$ & - & - & $3.046^{* * *}$ & $3.510^{* * * *}$ \\
\hline & $(0.316)$ & $(0.324)$ & & & $(0.344)$ & $(0.371)$ \\
\hline Observations & 219 & 219 & 219 & 219 & 165 & 165 \\
\hline Number of regions & 20 & 20 & 20 & 20 & 15 & 15 \\
\hline Number of years & 11 & 11 & 11 & 11 & 11 & 11 \\
\hline Dummies for year & No & No & Yes & Yes & No & No \\
\hline $\operatorname{AR}(1)$ & Yes & Yes & Yes & Yes & Yes & Yes \\
\hline Adjusted R-squared & 0.5482 & 0.5507 & 0.7472 & 0.7889 & 0.5307 & 0.5643 \\
\hline Wald test $\left(\right.$ Prob $\left.>\mathrm{chi}^{2}\right)$ & 0.0000 & 0.0000 & 0.0000 & 0.0000 & 0.0000 & 0.0000 \\
\hline
\end{tabular}

Source: authors' elaboration on data provided by Italian Ministry of Health, by Osservatorio Prezzi e Tecnologie and by ISTAT.

Notes: panel corrected standard error with heteroskedastic disturbance and first-order autocorrelation are reported in parentheses.

*** Denotes significance at 1 per cent level.

** Denotes significance at 5 per cent level.

* Denotes significance at 10 per cent level.

However, also this alternative measure shows some limits since it is affected by the implementation of tight expenditure caps. ${ }^{27}$ Thus, we replace the variable DRG with a variable that represents the share of regional funding actually allocated on fee schedule basis, defined and computed according to [38]. ${ }^{28}$ These additional tests largely confirm the robustness of our previous results.

Second, we check whether the level of the aggregate index of technology endowment in each region also depends on its previous level $t-1$. For this purpose, we apply a LSDV bias-corrected estimator $[43,44]$, which performs well in the case of small panel where GMM cannot be applied efficiently. ${ }^{29}$ Although some control variables lose their statistical significance, the results of these additional

\footnotetext{
27 For a more extensive discussion, see Section 2.2 .

28 We estimate such variable for each year and for each region, using as denominator the total regional expenditure for health care and as numerator the amount of funds allocated on fee schedule basis for hospital services derived from regional accounting system. Both data have been taken from Italian Ministry of Health website.

29 Since the inclusion of the lagged independent variable implies an evident problem of endogeneity a common solution would have been to use the GMM first-difference estimator originally proposed by [40] and
}

tests are generally supportive of those already reported in Tables 5 and 6.

Finally, we can disentangle each of the two indices into two components, a first one referring to public hospitals and a second one referring to private ones. The rationale is that public hospitals may have access to alternative ways of funding equipment purchases with respect to private sector, affecting the regional levels of technology endowment. To check for such effect we have re-run (1a) and (1b) limited only to the public hospitals component of the two indices of technology endowment. ${ }^{30}$ Also in this case, we find support that the per-case payment system has been associated with a lower level of regional technology endowment.

\section{Discussion}

The key tenet of many reforms of the hospital sector has been to introduce incentives for improving efficiency, adopting fairly anywhere some forms of prospective

\footnotetext{
further developed by $[41,42]$. However the reliability of GMM firstdifference estimator for small sample is doubtful $[43,44]$.

30 The descriptive statistics for these indices are reported in Tables A2 and A3 of the Appendix A.
} 
Table 6

Econometric results for most expensive pieces of equipment (H_EEI).

\begin{tabular}{|c|c|c|c|c|c|c|}
\hline $\begin{array}{l}\text { Model } \\
\text { Dependent variables }\end{array}$ & $\begin{array}{l}(1) \\
\text { H_EEI }\end{array}$ & $\begin{array}{l}(2) \\
\text { H_EEI }\end{array}$ & $\begin{array}{l}(3) \\
\text { H_EEI }\end{array}$ & $\begin{array}{l}(4) \\
\text { H_EEI }\end{array}$ & $\begin{array}{l}(5) \\
\text { H_EEI }\end{array}$ & $\begin{array}{l}(6) \\
\text { H_EEI }\end{array}$ \\
\hline Constant & $\begin{array}{l}-8.702^{* * *} \\
(3.521)\end{array}$ & $\begin{array}{l}-9.039^{* * *} \\
(3.553)\end{array}$ & $\begin{array}{l}-11.077^{* * *} \\
(3.453)\end{array}$ & $\begin{array}{l}-11.520^{* * *} \\
(3.513)\end{array}$ & $\begin{array}{l}-10.082^{* * *} \\
(3.587)\end{array}$ & $\begin{array}{l}-10.958^{* * * *} \\
(3.477)\end{array}$ \\
\hline GDP_POP & $\begin{array}{l}0.000^{* * * *} \\
(0.000)\end{array}$ & $\begin{array}{l}0.000^{* * * *} \\
(0.000)\end{array}$ & $\begin{array}{l}0.000^{* * *} \\
(0.000)\end{array}$ & $\begin{array}{l}0.000^{* * *} \\
(0.000)\end{array}$ & $\begin{array}{l}0.000^{* * *} \\
(0.000)\end{array}$ & $\begin{array}{l}0.000^{* * * *} \\
(0.000)\end{array}$ \\
\hline OLD & $\begin{array}{l}0.050 \\
(0.127)\end{array}$ & $\begin{array}{l}0.009 \\
(0.134)\end{array}$ & $\begin{array}{l}0.026 \\
(0.083)\end{array}$ & $\begin{array}{l}0.041 \\
(0.084)\end{array}$ & $\begin{array}{l}0.231 \\
(0.111)\end{array}$ & $\begin{array}{l}0.223^{* *} \\
(0.112)\end{array}$ \\
\hline DISCHARGE_POP & $\begin{array}{l}0.038^{* * *} \\
(0.014)\end{array}$ & $\begin{array}{l}0.040^{* * * *} \\
(0.014)\end{array}$ & $\begin{array}{l}0.044^{* * *} \\
(0.016)\end{array}$ & $\begin{array}{l}0.046^{* * * *} \\
(0.016)\end{array}$ & $\begin{array}{l}0.033^{* *} \\
(0.016)\end{array}$ & $\begin{array}{l}0.028^{*} \\
(0.016)\end{array}$ \\
\hline AMBULATORY_POP & $\begin{array}{l}0.032 \\
(0.021)\end{array}$ & $\begin{array}{l}0.002 \\
(0.022)\end{array}$ & $\begin{array}{l}0.037 \\
(0.026)\end{array}$ & $\begin{array}{l}0.039 \\
(0.026)\end{array}$ & $\begin{array}{l}0.028 \\
(0.017)\end{array}$ & $\begin{array}{l}0.022 \\
(0.018)\end{array}$ \\
\hline INFLOW & $\begin{array}{l}0.074 \\
(0.069)\end{array}$ & $\begin{array}{l}0.052 \\
(0.070)\end{array}$ & $\begin{array}{l}0.055 \\
(0.072)\end{array}$ & $\begin{array}{l}0.081 \\
(0.073)\end{array}$ & $\begin{array}{l}0.138^{*} \\
(0.080)\end{array}$ & $\begin{array}{l}0.136 \\
(0.083)\end{array}$ \\
\hline BEDS_POP & $\begin{array}{l}0.207 \\
(0.376)\end{array}$ & $\begin{array}{l}0.166 \\
(0.378)\end{array}$ & $\begin{array}{l}0.330 \\
(0.385)\end{array}$ & $\begin{array}{l}0.200 \\
(0.414)\end{array}$ & $\begin{array}{l}0.206 \\
(0.356)\end{array}$ & $\begin{array}{l}0.194 \\
(0.361)\end{array}$ \\
\hline PHYS_POP & $\begin{array}{l}9.558^{* * *} \\
(1.377)\end{array}$ & $\begin{array}{l}9.329^{* * * *} \\
(1.354)\end{array}$ & $\begin{array}{l}9.634^{* * * *} \\
(1.430)\end{array}$ & $\begin{array}{l}9.401^{* * *} \\
(1.400)\end{array}$ & $\begin{array}{l}9.975^{* * *} \\
(1.262)\end{array}$ & $\begin{array}{l}10.033^{* * *} \\
(1.265)\end{array}$ \\
\hline MIX_P\&P & $\begin{array}{l}-0.005 \\
(0.029)\end{array}$ & $\begin{array}{l}-0.005 \\
(0.029)\end{array}$ & $\begin{array}{l}-0.008 \\
(0.036)\end{array}$ & $\begin{array}{l}-0.005 \\
(0.031)\end{array}$ & $\begin{array}{l}-0.015 \\
(0.034)\end{array}$ & $\begin{array}{l}-0.015 \\
(0.034)\end{array}$ \\
\hline CASE_MIX & $\begin{array}{l}4.526^{* * *} \\
(1.373)\end{array}$ & $\begin{array}{l}4.420^{* * * *} \\
(1.386)\end{array}$ & $\begin{array}{l}6.334^{* *} \\
(2.948)\end{array}$ & $\begin{array}{l}6.425^{* *} \\
(2.939)\end{array}$ & $\begin{array}{l}8.206^{* * *} \\
(1.319)\end{array}$ & $\begin{array}{l}8.101^{* * *} \\
(1.328)\end{array}$ \\
\hline DRG & $\begin{array}{l}-4.230^{* *} \\
(1.884)\end{array}$ & $\begin{array}{l}-3.420^{*} \\
(1.849)\end{array}$ & $\begin{array}{l}-5.002^{* *} \\
(2.241)\end{array}$ & $\begin{array}{l}-3.857^{*} \\
(2.094)\end{array}$ & $\begin{array}{l}-6.800^{* * *} \\
(1.823)\end{array}$ & $\begin{array}{l}-6.771^{* * *} \\
(1.843)\end{array}$ \\
\hline REG_DRG & - & $\begin{array}{l}1.217^{* * * *} \\
(0.424)\end{array}$ & - & $\begin{array}{l}1.520^{* * * *} \\
(0.462)\end{array}$ & - & $\begin{array}{l}0.570 \\
(0.598)\end{array}$ \\
\hline TREND & $\begin{array}{l}1.468^{* * *} \\
(0.125)\end{array}$ & $\begin{array}{l}1.451^{* * * *} \\
(0.129)\end{array}$ & - & - & $\begin{array}{l}1.473^{* * *} \\
(0.118)\end{array}$ & $\begin{array}{l}1.439^{* * * *} \\
(0.132)\end{array}$ \\
\hline Observations & 219 & 219 & 219 & 219 & 165 & 165 \\
\hline Number of regions & 20 & 20 & 20 & 20 & 15 & 15 \\
\hline Number of years & 11 & 11 & 11 & 11 & 11 & 11 \\
\hline Dummies for year & No & No & Yes & Yes & No & No \\
\hline $\mathrm{AR}(1)$ & Yes & Yes & Yes & Yes & Yes & Yes \\
\hline Adjusted R-squared & 0.4381 & 0.4773 & 0.7035 & 0.7269 & 0.5726 & 0.5982 \\
\hline Wald test $\left(\right.$ Prob $\left.>\mathrm{chi}^{2}\right)$ & 0.0000 & 0.0000 & 0.0000 & 0.0000 & 0.0000 & 0.0000 \\
\hline
\end{tabular}

Source: authors' elaboration on data provided by Italian Ministry of Health, by Osservatorio Prezzi e Tecnologie and by ISTAT.

Notes: panel corrected standard error with heteroskedastic disturbance and first-order autocorrelation are reported in parentheses.

*** Denotes significance at 1 per cent level.

** Denotes significance at 5 per cent level.

* Denotes significance at 10 per cent level.

payment system and reducing the scope for global budgeting. Medical technology has been identified as one of the main causes of expenditures growth; thus, understanding the effects of financing mechanisms on technology diffusion becomes a relevant issue for health care policy.

This study offers a contribution to the literature on financing mechanisms and medical technology diffusion, by highlighting the consequences of the heterogeneity of reimbursement schemes of Italian regions on their levels of technology medical equipment.

We test the hypothesis that the differences across the regional reimbursement mechanisms, in terms of how extended is the use of the DRG system, impact on the change in the equipment endowment. Our results suggest

Table 7

Reimbursement regulation elasticities.

\begin{tabular}{|c|c|c|c|c|c|c|}
\hline Model & (1) & (2) & (3) & (4) & (5) & (6) \\
\hline $\begin{array}{l}\text { Dependent variable } \\
\text { DRG }\end{array}$ & $\begin{array}{l}\text { EEI } \\
-0.087^{* * *} \\
(0.020)\end{array}$ & $\begin{array}{l}\text { EEI } \\
-0.088^{* * *} \\
(0.019)\end{array}$ & $\begin{array}{l}\text { EEI } \\
-0.098^{* * *} \\
(0.020)\end{array}$ & $\begin{array}{l}\text { EEI } \\
-0.105^{* * *} \\
(0.019)\end{array}$ & $\begin{array}{l}\text { EEI } \\
-0.066^{* *} \\
(0.033)\end{array}$ & $\begin{array}{l}\text { EEI } \\
-0.067^{* *} \\
(0.031)\end{array}$ \\
\hline $\begin{array}{l}\text { Dependent variable } \\
\text { DRG }\end{array}$ & $\begin{array}{l}\text { H_EEI } \\
-0.115^{* *} \\
(0.053)\end{array}$ & $\begin{array}{l}\text { H_EEI } \\
-0.093^{*} \\
(0.052)\end{array}$ & $\begin{array}{l}\text { H_EEI } \\
-0.138^{*} \\
(0.065)\end{array}$ & $\begin{array}{l}\text { H_EEI } \\
-0.109^{*} \\
(0.060)\end{array}$ & $\begin{array}{l}\text { H_EEI } \\
-0.193^{* * *} \\
(0.054)\end{array}$ & $\begin{array}{l}\text { H_EEI } \\
-0.192^{* * *} \\
(0.054)\end{array}$ \\
\hline
\end{tabular}

Source: authors' elaboration on data provided by Italian Ministry of Health, by Osservatorio Prezzi e Tecnologie and by ISTAT.

Notes: the table reports, respectively in the first row and in the second row, the elasticities estimated of the variable DRG from the regression results of Tables 5 and 6.

Panel corrected standard error with heteroskedastic disturbance and first-order autocorrelation are reported in parentheses.

*** Denotes significance at 1 per cent level.

** Denotes significance at 5 per cent level.

* Denotes significance at 10 per cent level. 
that per case payment system is associated with lower level of technology endowment per million of inhabitants because of the related stringent budget constraints. This effect is particularly relevant in the case of the most expensive and complex medical equipment technology.

We are aware, however, that this paper suffers from some limitations mainly due to the lack of more detailed data on the features of the funding system, on the technical medical equipment and on its availability at the hospital level. Indeed, the indicators used to catch the differences in the reimbursement mechanism for hospital care across regions are far from being comprehensive and, at the same time, the weight of additional capital funding for technical medical equipment in each region cannot be assessed. Furthermore, data on a wider set of technical medical equipment as well as their availability at the hospital level would increase the explanatory power of our empirical setting, taking into account the institutional features of providers and their effects on technology adoption. Finally, under retrospective cost reimbursement system health care providers may over-invest in R\&D and medical technology, leading to the well-known "medical arm race" phenomenon. Thus, we acknowledge that regional systems where hospitals' funding is mainly based on a retrospective cost reimbursement mechanism may cause over-investments in expensive and complex medical equipment technology.

Unfortunately, we cannot investigate the efficient level of regional investments in medical equipment because of the lack of data. Hence, we only focus our attention on the effect of different regional reimbursement systems on the level of technology endowment.

Notwithstanding the above limitations, we believe that our study provides evidence that the endowment of medical equipment per million of inhabitants was affected by financial regulation of health care providers, above all in terms of how extended is the use of the DRG system.

From a policy viewpoint, our suggestion to policymakers is twofold. On the one hand, close attention should be taken when choosing the most appropriate financing schemes for health care to shape medical technology diffusion at regional or country level. When innovative pieces of technical equipment are involved, the frequency of updating of DRGs based payments may crucially affect technological diffusion. On the other hand, there are other factors that should not be neglected when designing medical technology diffusion policies such as demand and supply related variables and the degree of competition between private accredited and public hospitals. Focusing only on health care providers financing mechanisms, may lead to ineffective and counterproductive outcomes in terms of medical technology diffusion.

\section{Acknowledgements}

This paper draws on research undertaken as part of the InterQuality project 'International Research Project on Financing Quality in Healthcare', funded by the European Commission under the Seventh Framework
Programme (FP7) for Research and Technological Development (http://interqualityproject.eu/).

The authors are grateful to Aleksandra Torbica and Renato Balma for useful discussion on Italian capital funding system for medical equipment. The authors would like to thank Giovanni Fattore and two anonymous reviewers for their valuable comments and suggestions that helped us to improve the paper substantially. The usual disclaimer applies.

\section{Appendix A.}

In this Appendix A, we explain in detail the computation of our index of technology endowment (Equipment Endowment Index, EEI). EEI index is computed on the basis of the inventory of technical equipment available in the acute hospitals at regional level for the period 1997-2007, provided by Italian Ministry of Health. To the best of our knowledge, no data at hospital level are public available and, thus, our unit of observation is represented by each Italian region.

During the period under observation, the inventory of medical equipment has changed in terms of amount and composition. To get a homogeneous set of medical equipment, we consider only those for which information, including the estimated purchase cost, is available across the whole observation period. Table A1 reports the list of the 16 pieces of technical equipment in our data set, the estimated values, at 2000 fixed prices, and the relative weights.

The estimated value is calculated on the basis of the purchase costs of the different medical equipment, employing data provided by Observatory of prices and technologies (Osservatorio Prezzi e Tecnologie). This data set offers a detailed classification of medical equipment, based on categories of technically homogenous piece of equipment and prices based on the purchases by a large sample of Italian

Table A1

List of technical equipment included in the data set.

\begin{tabular}{lrc}
\hline Technical equipment & Estimated value ${ }^{\mathrm{a}}$ & Weight \\
\hline Magnetic resonance imaging (MRI) & $2,232,673.02$ & 1.0000 \\
Linear accelerators and components & $1,490,187.65$ & 0.6674 \\
CT-scanner & $787,041.28$ & 0.3525 \\
Computerised gamma camera & $622,275.03$ & 0.2787 \\
Medical imaging table & $317,508.00$ & 0.1422 \\
Ultrasound system & $209,999.90$ & 0.0941 \\
Mobile X-ray system & $139,782.09$ & 0.0626 \\
Analogic X-ray system & $136,073.66$ & 0.0609 \\
Immunoassay analyser & $66,707.05$ & 0.0299 \\
Anaesthesia machine & $57,644.96$ & 0.0258 \\
Differential haematology analyser & $53,210.39$ & 0.0238 \\
Monitor & $47,993.70$ & 0.0215 \\
Surgical light & $36,436.27$ & 0.0163 \\
Continuous ventilator system & $31,715.75$ & 0.0142 \\
Automatic immunochemistry system & $25,490.73$ & 0.0114 \\
Haemodialysis delivery system & $20,133.51$ & 0.0090 \\
\hline
\end{tabular}

Source: our elaboration based on data provided by Italian Minister of Health and by Osservatorio Prezzi e Tecnologie.

a Estimated at 2000 fixed prices. 
Table A2

Index of regional endowment of medical equipment (EEI), per million of inhabitants.

\begin{tabular}{|c|c|c|c|c|c|c|}
\hline \multirow[t]{2}{*}{ Region } & \multicolumn{2}{|l|}{ EEI } & \multicolumn{2}{|c|}{ EEI_PUBLIC (public hospitals) } & \multicolumn{2}{|c|}{$\begin{array}{l}\text { EEI_PRIVATE (private } \\
\text { accredited hospitals) }\end{array}$} \\
\hline & Mean & $\Delta \%$ 1997-2007 & Mean & $\Delta \% 1997-2007$ & Mean & $\Delta \% 1997-2007$ \\
\hline Abruzzo & 72.63 & $93.20 \%$ & 57.06 & $81.32 \%$ & 15.57 & $140.94 \%$ \\
\hline Basilicata & 53.64 & $151.85 \%$ & 52.09 & $151.52 \%$ & 1.55 & $166.54 \%$ \\
\hline Calabria & 66.63 & $84.03 \%$ & 46.22 & $79.30 \%$ & 20.41 & $95.79 \%$ \\
\hline Campania & 54.97 & $71.79 \%$ & 38.91 & $69.83 \%$ & 16.05 & $76.36 \%$ \\
\hline Emilia Romagna & 87.13 & $223.41 \%$ & 72.81 & $251.79 \%$ & 14.33 & $129.85 \%$ \\
\hline Friuli V.G. & 82.58 & $24.81 \%$ & 75.37 & $18.31 \%$ & 7.21 & $117.14 \%$ \\
\hline Lazio & 80.95 & $53.52 \%$ & 62.89 & $85.44 \%$ & 18.06 & $-8.81 \%$ \\
\hline Liguria & 79.15 & $76.10 \%$ & 77.95 & $77.96 \%$ & 1.20 & $4.70 \%$ \\
\hline Lombardy & 84.19 & $38.96 \%$ & 68.29 & $41.92 \%$ & 15.89 & $26.76 \%$ \\
\hline Marche & 88.56 & $44.91 \%$ & 77.83 & $42.77 \%$ & 10.73 & $64.99 \%$ \\
\hline Molise & 97.44 & $206.35 \%$ & 86.34 & $209.81 \%$ & 11.10 & $183.95 \%$ \\
\hline Piedmont & 74.52 & $100.31 \%$ & 65.20 & $86.40 \%$ & 9.32 & $248.66 \%$ \\
\hline Puglia & 64.95 & $53.87 \%$ & 54.87 & $53.18 \%$ & 10.08 & $57.48 \%$ \\
\hline Sardinia & 70.83 & $119.57 \%$ & 59.94 & $131.28 \%$ & 10.89 & $69.35 \%$ \\
\hline Sicily & 63.47 & $76.88 \%$ & 49.86 & $71.64 \%$ & 13.61 & $97.12 \%$ \\
\hline Toscana & 80.20 & $50.81 \%$ & 74.37 & $53.43 \%$ & 5.82 & $25.98 \%$ \\
\hline Trentino A.A. & 97.29 & $25.51 \%$ & 89.50 & $24.26 \%$ & 7.79 & $40.74 \%$ \\
\hline Umbria & 89.32 & $57.74 \%$ & 83.60 & $61.50 \%$ & 5.72 & $11.77 \%$ \\
\hline Valle d'Aosta ${ }^{\mathrm{a}}$ & 86.14 & $21.30 \%$ & 86.14 & $21.30 \%$ & 0.00 & $0.00 \%$ \\
\hline Veneto & 77.85 & $47.59 \%$ & 73.99 & $47.10 \%$ & 3.85 & $57.17 \%$ \\
\hline Total & 77.62 & $83.69 \%$ & 67.66 & $85.84 \%$ & 9.96 & $70.67 \%$ \\
\hline
\end{tabular}

Source: our elaboration on data provided by Italian Ministry of Health and by Osservatorio Prezzi e Tecnologie.

Note: data are weighted by population and the mean is computed across years.

a Data for this region are available starting with 1998.

Table A3

Index of regional endowment of the four most expensive medical equipment (H_EEI), per million of inhabitants.

\begin{tabular}{|c|c|c|c|c|c|c|}
\hline \multirow[t]{2}{*}{ Region } & \multicolumn{2}{|l|}{ H_EEI } & \multicolumn{2}{|c|}{ H_EEI_PUBLIC (public hospitals) } & \multicolumn{2}{|c|}{$\begin{array}{l}\text { H_EEI_PRIVATE (private } \\
\text { accredited hospitals) }\end{array}$} \\
\hline & Mean & $\Delta \% 1997-2007$ & Mean & $\Delta \% 1997-2007$ & Mean & $\Delta \% 1997-2007$ \\
\hline Abruzzo & 21.19 & $146.10 \%$ & 14.91 & $155.55 \%$ & 6.28 & $124.15 \%$ \\
\hline Basilicata & 11.14 & $494.55 \%$ & 10.55 & $477.91 \%$ & 0.59 & $0.07 \%$ \\
\hline Calabria & 19.10 & $183.99 \%$ & 11.22 & $229.66 \%$ & 7.88 & $133.90 \%$ \\
\hline Campania & 15.09 & $133.57 \%$ & 9.45 & $135.50 \%$ & 5.65 & $130.70 \%$ \\
\hline Emilia Romagna & 18.64 & $311.16 \%$ & 13.14 & $419.03 \%$ & 5.51 & $161.03 \%$ \\
\hline Friuli V.G. & 21.99 & $79.70 \%$ & 19.47 & $53.04 \%$ & 2.52 & $731.09 \%$ \\
\hline Lazio & 24.54 & $68.72 \%$ & 17.53 & $132.03 \%$ & 7.01 & $-3.20 \%$ \\
\hline Liguria & 19.34 & $153.33 \%$ & 19.30 & $158.33 \%$ & 0.04 & $-100.00 \%$ \\
\hline Lombardy & 21.52 & $59.05 \%$ & 15.61 & $78.92 \%$ & 5.91 & $18.21 \%$ \\
\hline Marche & 22.58 & $140.18 \%$ & 19.22 & $132.08 \%$ & 3.35 & $227.36 \%$ \\
\hline Molise & 28.30 & $518.93 \%$ & 23.81 & $623.73 \%$ & 4.50 & $237.45 \%$ \\
\hline Piedmont & 20.97 & $145.26 \%$ & 17.04 & $118.47 \%$ & 3.93 & $325.16 \%$ \\
\hline Puglia & 16.68 & $82.82 \%$ & 12.92 & $105.84 \%$ & 3.75 & $29.95 \%$ \\
\hline Sardinia & 19.25 & $193.28 \%$ & 15.33 & $232.94 \%$ & 3.92 & $95.54 \%$ \\
\hline Sicilia & 15.41 & $155.33 \%$ & 10.15 & $149.75 \%$ & 5.26 & $166.43 \%$ \\
\hline Toscana & 18.91 & $122.85 \%$ & 17.74 & $133.81 \%$ & 1.18 & $37.15 \%$ \\
\hline Trentino A.A. & 17.52 & $88.88 \%$ & 14.16 & $69.82 \%$ & 3.35 & $202.03 \%$ \\
\hline Umbria & 19.46 & $104.69 \%$ & 17.98 & $123.88 \%$ & 1.48 & $-16.77 \%$ \\
\hline Valle d'Aosta* & 19.53 & $590.06 \%$ & 19.53 & $590.06 \%$ & 0.00 & $0.00 \%$ \\
\hline Veneto & 19.21 & $86.54 \%$ & 17.61 & $83.81 \%$ & 1.60 & $119.19 \%$ \\
\hline Total & 19.52 & $159.47 \%$ & 15.83 & $176.28 \%$ & 3.69 & $103.23 \%$ \\
\hline
\end{tabular}

Source: our elaboration on data provided by Italian Ministry of Health and Osservatorio Prezzi e Tecnologie.

Note: data are weighted by population and the mean is computed across years.

a Data for this region are available starting with 1998.

public health care organisations, both hospitals and local health authorities (ASL), in the period 1995-2005. ${ }^{31}$

\footnotetext{
31 The classification system was established by Consorzio per l'Area di ricerca di Trieste and further developed by Age.NAS (Agenzia nazionale per
}

The relative weights in Table A1 are computed according to the formula presented in Section 2.1.

i servizi sanitari regionali) of Italian Ministry of Health. For further details, see http://www.agenas.it/opt.html. 
Table A2 shows the regional values of the indicator of endowment of medical equipment (EEI), computed for the overall hospital sector as well as for the public hospitals and for the private accredited hospitals. Table A2 also reports the rate of change occurred in the period 1997-2007.

Data reveal a quite strong variability of the values of the index across regions in terms of both the overall availability of equipment and the public and private endowment. The dynamics of the indicator is also remarkably different in each region.

As we said before, the index EEI considers 16 different types of equipment, some of which are very different, at least in terms of prices (see Table A1). For instance, the relative price of the most expensive equipment in our dataset (MRI) is about ten times the price of the least expensive one (haemodialysis delivery system). Thus, we have also focused on the four most expensive pieces of equipment in our dataset (linear accelerators and components, computerised gamma camera, CT - scanner and MRI), and we have computed the index H_EEI for this subset of equipment. Table A3 shows the values of this index (H_EEI) for each region.

\section{References}

[1] Bokhari F. Managed care competition and the adoption of hospital technology: the case of cardiac catherization. International Journal of Industrial Organization 2009;27:223-37.

[2] Finkelstein A. The aggregate effects of health insurance: evidence from the introduction of medicare. NBER Working Paper Series; 2005. p. 11619.

[3] Baker L, Phibbs C. Managed care, technology adoption and healthcare: the adoption of neonatal intensive care. RAND Journal of Economics 2002;33:524-48.

[4] Pita-Barros P, Martinez-Giralt X. Technological adoption in health care. Universidade Nova de Lisboa working paper series; 2010. p. 545.

[5] Smith S, Newhouse JP, Freeland MS. Income, insurance, and technology: why does health spending outspace economic growth. Health Affairs 2009;28:1276-84.

[6] Organization for Economic Cooperation and Development (OECD). Health technologies and decision making; 2005. Paris.

[7] Spetz J, Maiuro LS. Measuring levels of technology in hospitals. Quarterly Review of Economics and Finance 2004;44(3):430-47.

[8] Cappellaro G, Ghislandi S, Anessi-Pessina E. Diffusion of medical technology: the role of financing. Health Policy 2011;100(1):51-9.

[9] Goddeeris JH. Medical insurance, technological change, and welfare Economic Inquiry 1984;22:56-67.

[10] Baumgardner JR. The interaction between forms of insurance contract and types of technical change in medical care. RAND Journal of Economics 1991;22:36-53.

[11] Selder A. Physician reimbursement and technology adoption. Journal of Health Economics 2005;24:907-30.

[12] Miraldo M. Hospital financing and the development and adoption of new technologies. University of York Center for Health Economics, CHErp Working Paper Series; 2007. p. 26.

[13] Levaggi R, Moretto M. Investment in hospital care technology under different purchasing rules: a real option approach. Bulletin of Economic Research 2008;60(2):159-81.

[14] Romeo AA, Wagner JL, Lee RH. Prospective reimbursement and the diffusion of new technologies in hospitals. Journal of Health Economics 1984;3:1-24.

[15] Hirth RA, Chernew ME, Orzol SM. Ownership, competition and the adoption of new technologies and cost-saving practices in a fixedprice environment. Inquiry 2000;37:282-94.

[16] Ikegami N. Health technology development in Japan. International Journal of Technological Assessment in Health Care 1988;4:239-54

[17] Bryce CL, Cline KE. The supply and use of selected medical technologies. Health Affairs 1998;17(1):213-24.

[18] McClellan M, Kessler D. A global analysis of technological change in health care: the case of heart attacks. Health Affairs $1999 ; 18(3): 250-5$.
[19] Burke M, Fournier G, Prasad K. The diffusion of a medical innovation: is success in the stars? Southern Economic Journal 2007;73(3):588-603.

[20] Slade E, Anderson G. The relationship between per capita income and diffusion of medical technologies. Health Policy 2001;58(1):1-14.

[21] Mas N, Seinfeld J. Is managed care restraining the adoption of technology by hospitals? Journal of Health Economics 2008;27:1026-45

[22] Baker L, Wheeler S. Managed care and technology diffusion: the case of MRI. Health Affairs 1998;17(5):195-207.

[23] Baker L, Brown M. Managed care, consolidation among health care providers, and health care: evidence from mammography. RAND Journal of Economics 1999;30(2):351-4.

[24] Bech M, Christiansen T, Dunham K, Lauridsen J, Lyttkens $\mathrm{CH}$, McDonald $\mathrm{K}$, et al. The influence of economic incentives and regulatory factors on the adoption of treatment technologies: a case study of technologies used to treat heart attacks. Health Economics 2009;18(10):1114-32.

[25] Cutler DM, McClellan MB. The determinants of technological change in heart attack treatment. NBER working paper series; 1996. p. 5751.

[26] Baker L, Spetz J. Managed care and medical technology growth. In: Garber AM, editor. Frontiers in health policy research, vol. 2. Cambridge, MA: MIT Press; 1999. p. 27-52.

[27] Fattore G, Torbica A. Inpatient reimbursement system in Italy: how do tariffs relate to costs. Health Care Management Science 2006;9:251-8.

[28] Guccio C. Le politiche di riforma organizzativa e istituzionale nel sistema ospedaliero, italiano. In: Guccio C, Pignataro G, Rizzo I, editors. Finanziamento e valutazione dei servizi ospedalieri. Milano: Franco Angeli; 2005. p. 15-53.

[29] Anessi-Pessina E, Cantù E, Jommi C. Phasing our market mechanisms in the Italian National Health Service. Public Money \& Management 2004;24(5):309-16.

[30] Morandi I. Sistemi regionali di ripartizione del fondo sanitario e di remunerazione dei ricoveri per acuti, di riabilitazione e di lungodegenza. Analisi della normativa vigente al 30 October 2008. Rome: AGENAS; 2008.

[31] Morandi I, Arcangeli L. Le tariffe nazionali e regionali. Quaderni di Monitor 2009;5(Suppl.):60-73.

[32] Morandi I, Pieroni E, Giuliani F, Cislaghi C. Criticità delle tariffe nel SSN. In: Paper presented at the annual meeting of AIES. 2008.

[33] Pignataro G, Rizzo I. Chi contratta con gli erogatori di prestazioni sanitarie? In: Guccio C, Pignataro G, Rizzo I, editors. Finanziamento e valutazione dei servizi ospedalieri. Milano: Franco Angeli; 2005. p. 77-90.

[34] Morandi I. Le tariffe ospedaliere in Italia: nazionali e regionali, presentation at the AIES-AGENAS meeting "Le tariffe in sanità: strumento di finanziamento regolazione e valutazione"; 2009. Rome.

[35] Carbone C, Jommi C, Torbica A. Tariffe e finanziamento dell'innovazione tecnologica: analisi generale e focus su due casi regionali. In: Anessi Pessina E, Cantù E, editors. L'aziendalizzazione della Sanità in Italia, Rapporto OASI 2006. Milano: EGEA; 2006.

[36] Guccio C, Pignataro G, Rizzo I. Efficiency of procurement procedures for medical devices. Rivista di Politica Economica 2006;I-II:135-58.

[37] Wooldridge J. Econometric analysis of cross section and panel data. Cambridge, MA: MIT Press; 2002.

[38] Cantù E, Carbone C, Anessi Pessina E. Do Italian regions effectively use DRG funding to steer provider behavior? In: Ongaro E, Massey A, Holzer M, Wayenberg E, editors. Policy, performance and management in governance and intergovernmental relations: transatlantic perspectives. Cheltenham, UK: Edward Elgar Publishing; 2011. p. 341-59.

[39] O’Reilly J, Busse R, Häkkinen U, Or Z, Street A, Wiley M. Paying for hospital care: the experience with implementing activity-based funding in five European countries. Health Economics, Policy and Law 2012;7(Special Issue 01):73-101.

[40] Arellano M, Bond S. Some tests of specification for panel data: Monte Carlo evidence and an application to employment equations. Review of Economic Studies 1991;58:277-97.

[41] Arellano M, Bover O. Another look at the instrumental variable estimation of error-components models. Journal of Econometrics 1995;68:29-51.

[42] Blundell R, Bond S. Initial conditions and moment restrictions in dynamic panel data models. Journal of Econometrics 1998;87:115-43.

[43] Bruno GSF. Approximating the bias of the LSDV estimator for dynamic unbalanced panel data models. Economics Letters 2005;87(3):361-6.

[44] Bruno GSF. Estimation and inference in dynamic unbalanced panel data models with a small number of individuals. Stata Journal 2005;5(4):473-500. 
[45] Laffont JJ, Tirole J. A theory of incentives in procurement and regulation. Cambridge, MA: The MIT Press; 1993.

[46] Quentin W, Scheller-Kreinsen D, Busse R. Technological innovation in DRG-based hospital payment systems across Europe. In: Busse R, Geisler A, Quentin W, Wiley M, editors. Diagnosis-related groups in Europe. European Observatory on Health Systems and Policies Series. Maidenhead, UK: Open University Press-McGraw-Hill; 2011.

[47] Scheller-Kreinsen D, Quentin W, Busse R. DRG-based hospital payment systems and technological innovation in 12 European countries. Value in Health 2011;14:1166-72.

[48] Levaggi R, Moretto M, Pertile P. DRGs: the link between investment in technologies and appropriateness. Working paper series. Department of Economics, University of Verona; 2012. WP n 31.
[49] Assobiomedica I sistemi tariffari per le prestazioni di assistenza ospedaliera Un esame della normativa nazionale e regionale. Secondo aggiornamento, Centro Studi Assobiomedica, $\mathbf{n}^{\circ}$ 10 June 2010.

[50] Assobiomedica I sistemi tariffari per le prestazioni di assistenza ospedaliera Un esame della normativa nazionale e regionale. Terzo aggiornamento, Centro Studi Assobiomedica, n ${ }^{\circ}$ 16 December 2012.

[51] France G, Taroni F, Donatini A. The Italian health care system. Health Economics 2005;14:S187-202.

[52] Cavalieri M, Gitto L, Guccio C. Reimbursement systems and quality of hospital care: an empirical analysis for Italy. Health Policy 2013;111:273-89. 